\title{
Effects of Several Effective Microorganisms (EM) on the Growth of Chinese cabbage (Brassica rapa)
}

\author{
Khalid A. Hussein and Jin Ho Joo* \\ Department of Biological Environment, Kangwon National University, 192-1 Hyo-Ja Dong,
}

Chuncheon, Kangwon-do 200-701, South Korea

\begin{abstract}
The development of satisfactory alternatives for supplying the nutrients needed by crops could decrease the problems associated with conventional NPK chemical fertilizers. In this study, the effects of bacterial and fungal effective microorganisms (EM) on the growth of Chinese cabbage (Brassica rapa) were evaluated. This investigation was carried out parrallel with conventional NPK chemical fertilizer and a commercial sold microbial fertilizer to compare between each of their effect. Sterile water and molasses were served as controls. Azotobacter chroococcum effect also was studied either alone or in combination with the effective microorganisms on the growth parameters. In contrast to the bacterial EM, the fungal EM alone without A. chroococcum had a more stimulating effect than fungal EM combined with $A$. chroococcum. Results showed that seedling inoculation significantly enhanced $B$. rapa growth. Shoot dry and fresh weight, and leaf length and width significantly were increased by both bacterial and fungal inoculation. The results indicated that the NPK chemical fertilizer deteriorates the microflora inhabiting the soil, while the effective microorganisms either fungal or bacterial ones increased the microbial density significantly. This study implies that both of fungal and bacterial EM are effective for the improvement of the Chinese cabbage growth and enhance the microorganisms in soil. The results showed antagonism occurred between $A$. chroococcum and each of Penicillium sp and Trichoderma sp in both agar and plant assays. The data were statistically analyzed by ANOVA and Dunnett test.
\end{abstract}

Key words: Effective microorganisms, Chinese cabbage, Azotobacter chroococcum, Antagonism

\section{Introduction}

The intensive use of chemical fertilizers has side effects in polluting underground water, destroying microorganisms and insects, making plants more susceptible to the attack of diseases and reducing soil fertility (Abdelaziz et al., 2007). Therefore, the development of satisfactory alternatives for supplying the nutrients needed by crops could decrease the problems associated with conventional NPK chemical fertilizers. Soils contain natural reserves of plant nutrients, but these reserves are largely in forms unavailable to plants, and only a minor portion is released each year through biological activities or chemical processes. This release is too slow to compensate for the removal of nutrients by agricultural production and to meet crop requirements (Chen, 2006). Therefore, biofertilizers are

\footnotetext{
Received : July 13. 2011 Accepted : August 16. 2011

*Corresponding author : Phone: +82332506448

E-mail: jhjoo@kangwon.ac.kr
}

designed to supplement the nutrients already present in the soil. Biofertilizers comprise microbial inocula or assemblages of living microorganisms which exert direct or indirect benefits on plant growth and crop yield through different mechanisms (Fuentes-Ramirez and CaballeroMellado, 2005). These microorganisms are able to fix atmospheric nitrogen or solubilize phosphorus, decompose organic material, or oxidize sulfur in the soil properties (Marin, 2006). Biofertilizers, commonly known as microbial inoculants are produced from cultures of certain soil organisms that can improve soil fertility and crop productivity such as mycorrhizae (Malik et al., 2005; Marin, 2006). One of the world's most commonly used term in the concept of biofertilizer is "effective microorganisms" (EM). Azotobacter sp. can produce antifungal compounds to fight against many plant pathogens. They also increase germination and vigor in young plants leading to improved crop stands (Chen, 2006). Kloepper et al. (1992) has shown that wheat yield increased up to $30 \%$ with Azotobacter inoculation and up to $43 \%$ with 
Bacillus inoculation. Other fungal biofertilizers which have been used to improve plant growth are Penicillium species (Kaewchai et al., 2009). They are phosphate solubilizing microorganisms that improve phosphorus absorption in plants and stimulate plant growth (Wakelin et al., 2004; Pradhan and Sukla, 2005). Fungal biofertilizers include plant growth stimulating fungi e.g. Trichoderma, enzymatic producing fungi for compost production and P-solubilizing fungi and K-solubilizing fungi. Fungal biofertilizers play an important role in promoting plant growth, health, productivity and improving soil fertility (Kaewchai et al 2009). Trichoderma species can not only reduce the occurrence of disease and inhibit pathogen growth when used as mycofungicides, but they also increase the growth and yield of plants (Harman et al., 2004; Vinale et al., 2008). They also increase the survival of seedlings, plant height, leaf area and dry weight (Kleifeld and Chet, 1992). Trichoderma species improve mineral uptake, release minerals from soil and organic matter, enhance plant hormone production, induce systematic resistance mechanisms, and induced root systems in hydroponics (Yedidia et al., 1999). For these reasons Trichoderma species are known as plant growth promoting fungi (Hyakumachi and Kubota, 2004; HerreraEstrella and Chet, 2004) or are increasing plant growth (biofertilization) (Benítez et al., 2004). Mycofungicides and fungal biofertilizers are presently used on a very small scale as compared to chemical compounds (Fravel, 2005). There is still a wide gap between the considerable, often unpublished research carried out in laboratories as compared to development for use in the field. Future research should therefore develop fungal products which have significant effects in field applications and that are also stable when stored. A plastic film house experiment was carried out to investigate the effects of several effective microorganisms of bacterial and fungal application in order to improve the yield quality and productivity of Chinese cabbage.

\section{Materials and Methods}

Natural silty clay soil was sieved via $2 \mathrm{~mm}$ mesh. The soil was mixed well manually with manure at the rate of $1,000 \mathrm{~kg}_{10 \mathrm{a}^{-1}}$. Twenty $\mathrm{cm}$ diameter pots were filled with soil up to $1 \mathrm{~cm}$ of the top. Soil in all pots was damp but not to the saturation level. Pots were divided into nine groups (Table 1) with triplicate. Group one was the negative control with only water added throughout the study. Group two was a second control treated with $40 \mathrm{ml} 5$ days $^{-1}$ pot $^{-1}$ sterilized molasses. Group three was given the manufactured NPK chemical fertilizer at the rate of $\mathrm{N}^{-} \mathrm{P}_{2} \mathrm{O}_{5}-\mathrm{K}_{2} \mathrm{O}(200-$ $78-110 \mathrm{~kg} \mathrm{ha}^{-1}$ ) as basal fertilization. Group four was given $40 \mathrm{ml} 5$ days $^{-1}$ pot $^{-1}$ commercial EM solution. Group five was given bacterial EM mixture "Lactobacillius kefir, Rhodobacter $\mathrm{sp}$., Bacillus cereus, Pseudomonas fluorescens, and Pseudomonas auregenosa" $40 \mathrm{ml} 5$ days $^{-1}$ pot $^{-1}$. Group six was given the bacterial EM mixture plus Azotobacter chroococum $40 \mathrm{ml} 5$ days $^{-1} \operatorname{pot}^{-1}$. Group seven was given fungal EM "Penicillium chrysogenum and Trichoderma sp." plus Azotobacter chroococum $40 \mathrm{ml} 5$ days $^{-1}$ pot $^{-1}$. Group eight was given only fungal EM "Penicillium chrysogenum and Trichoderma sp." $40 \mathrm{ml} 5$ days $^{-1}$ pot $^{-1}$. Group nine was given Azotobacter chroococcum alone $40 \mathrm{ml} 5$ days $^{-1}$ pot $^{-1}$. The experiment elapsed 35 days prior to harvest Chinese cabbage and measure growth parameters. So, the total volume added of EM solution to each treatment was $280 \mathrm{~mL} /$ pot (Table 1).

Table 1. The groups of microorganisms used as effective microorganisms (EM).

\begin{tabular}{ll}
\hline \hline Group & Treatments \\
\hline Group 1 & Only water \\
Group 2 & Sterilized molasses \\
Group 3 & NPK chemical fertilizer \\
Group 4 & Commercial EM solution \\
Group 5 & Bacterial EM (Lactobacillus kefir, Rhodobacter sp., Bacillus cereus, Pseudomonas fluorescens, and \\
& Pseudomonas auregenosa) \\
Group 6 & Azotobacter chroococum + Bacterial EM (Lactobacillus kefir, Rhodobacter sp., Bacillus cereus, \\
Group 7 & Azotobacter chroococum + Fungal EM (Penicillium chrysogenum and Trichoderma sp) \\
Group 8 & Fungal EM (Penicillium chrysogenum and Trichoderma sp) \\
Group 9 & Only Azotobacter chroococum \\
\hline
\end{tabular}


EM species either bacteria or fungi were cultivated in molasses separately to avoid antagonistic action inside the media. The cultures were also incubated separately for three days in convenient conditions before application to the soil. Each soil group was inoculated by its corresponding treatment one week before planting of the seedlings. EM species were mixed evenly in equal amounts only before the application to their corresponding group. The seedlings roots were immersed in the EM solution corresponding to their groups. Water was provided on demand to all plants. Measurements of the chlorophyll using Chlorophyll Meter (SPAD-502PLUS) were determined twice (two weeks and five weeks after seedlings). Root length, root fresh weight, shoot dry weight, shoot fresh weight, leaf's length, and width were measured after five weeks. The microbial densities of the fresh soils were measured for the all treatments and control (Chaudhary and Iqbal, 2006). The fresh and dry weights were weighed by an analytical balance (High-precision Balance). Plants were dried at $75^{\circ} \mathrm{C}$ for 24 hours.

\section{Cultivation of Microorganisms}

Bacterial and fungal species were isolated from the rhizosphere of Pinus sylvestris shrubs in the forest area near Kangwon National University, Chuncheon, Korea. Pseudomonas Agar F selective media was used to isolate the pseudomonas species. The media was prepared by adding pancreatic digest of casein $10 \mathrm{~g}$; proteose peptone $10 \mathrm{~g} ; \mathrm{K}_{2} \mathrm{HPO}_{4} 1.5 \mathrm{~g} ; \mathrm{MgSO}_{4} \cdot 7 \mathrm{H}_{2} \mathrm{O} 1.5 \mathrm{~g}$; and Agar $15 \mathrm{~g}$ to $1,000 \mathrm{~mL}$ of distilled water. Lactobacillus species was isolated on Lactobacilli MRS Agar as selective media which contained proteose peptone $10 \mathrm{~g}$; beef Extract $10 \mathrm{~g}$; yeast extract $5 \mathrm{~g}$; dextrose $20 \mathrm{~g}$; polysorbate $1 \mathrm{~g}$; ammonium citrate $2 \mathrm{~g}$; sodium acetate $5 \mathrm{~g}$; magnesium sulfate $0.1 \mathrm{~g}$; manganese sulfate $0.05 \mathrm{~g}$; dipotassium phosphate $2 \mathrm{~g}$; agar $15 \mathrm{~g}$ (pH 6.5) per 1,000 $\mathrm{mL}$ of distilled water. The bacterial species were purified and examined microscopically. All bacterial species were preserved on slant cultures of Nutrient Agar media (pH 6.8) which contained peptone 5 $\mathrm{g}$; yeast extract, $3 \mathrm{~g}$; agar, $15 \mathrm{~g}$ per 1,000 $\mathrm{mL}$ of distilled water. The fungal species were isolated and preserved on slant cultures using Czapek's Agar media ( $\mathrm{pH} 7.3$ ) which contained/ liter of distilled water glucose $30 \mathrm{~g} ; \mathrm{NaNO}_{3} 3 \mathrm{~g}$; $\mathrm{KH}_{2} \mathrm{PO}_{4} 1 \mathrm{~g} ; \mathrm{MgSO}_{4} \cdot 7 \mathrm{H}_{2} \mathrm{O} 0.5 \mathrm{~g} ; \mathrm{KCl} 0.5 \mathrm{~g} ;\left(\mathrm{NH}_{4}\right) \mathrm{H}_{2} \mathrm{PO}_{4}$ $10 \mathrm{~g}$; $\mathrm{FeSO}_{4} \cdot 7 \mathrm{H}_{2} \mathrm{O} 0.01 \mathrm{~g}$; Agar $15 \mathrm{~g}$ a $1,000 \mathrm{~mL}$ of distilled water.

\section{Antagonism Tests}

Fungal and bacterial species were activated on their convenient media, agar discs ( $15 \mathrm{~mm}$ diameter) were cut from well growing culture with a sterile cork-borer and transferred to another agar surface, which was seeded about $10^{5}$ spores $/ \mathrm{mL}$ with the another antagonistic species. The plates were kept overnight in the $4^{\circ} \mathrm{C}$ refrigerator to allow the diffusion of the metabolites from the discs to the surrounding medium without growing of the antagonistic species. The plates were incubated in the appropriate temperature for 2-3 days. The plates were examined for inhibition zones. This agar disc antagonism method was repeated among bacterial species, fungal species, and Azotobacter against both fungal and bacterial species (Patel and Brown, 1969).

Data was compared by analysis of variance (ANOVA) and Dunnett test as a post-hoc test (multiple comparisons) to see the differences between controls and treatment groups.

\section{Microbial Analysis}

Fresh soil samples were stored at $44^{\circ} \mathrm{C}$ for microbiological analyses. Heterotrophic bacterial and fungal populations were estimated by the plate count method. Soil suspension and dilutions were prepared in sterilized and distilled water. Media of nutrient agar (NA), rosebengal starch casein nitrate agar (RBSCNA) and modified potato dextrose agar (MPDA) were prepared in laboratory and used for determination of total soil bacterial, actinomycetes and fungi populations, respectively (Alef and Nannipieri 1995). Each solid medium was inoculated with $0.1 \mathrm{~cm}^{3}$ of soil dilution. It was incubated at $27^{\circ} \mathrm{C}$. The numbers of colonies on each medium were counted and reported as CFU (colony-forming units)/g soil. The media for Azotobacter enumeration was a solid and $\mathrm{N}$-free medium which contained sucrose, mineral salts, bromothymole blue and agar (LG medium). Colony-forming units on the solid media were numbered after a week of incubation at $27^{\circ} \mathrm{C}$ (Alef and Nannipieri 1995, Subba Rao 2001).

\section{Results and Discussion}

Many studies have shown that applying effective microorganisms increase crop productivity and diseases 
Table 2. Effects of different EM inoculations on the Chinese cabbage growth.

\begin{tabular}{|c|c|c|c|c|c|c|c|c|c|c|}
\hline \multirow{2}{*}{ No. } & \multirow{2}{*}{ Treatments } & \multicolumn{2}{|c|}{$\begin{array}{l}\text { Leaf chlorophyll } \\
\text { (SPAD unit) }\end{array}$} & \multicolumn{2}{|c|}{ Root } & \multicolumn{2}{|c|}{ Shoot } & \multicolumn{2}{|c|}{ Leaf } & \multirow{2}{*}{$\begin{array}{l}\mathrm{R} / \mathrm{S} \text { ratio } \\
\text { Fresh wt. }\end{array}$} \\
\hline & & $\begin{array}{c}\text { After } 2 \\
\text { weeks }\end{array}$ & $\begin{array}{l}\text { After } 5 \\
\text { weeks }\end{array}$ & $\begin{array}{c}\text { Fresh } \\
\text { wt. }\end{array}$ & Length & Dry wt. & Fresh wt. & Width & Length & \\
\hline 1 & Water & $44.2 \mathrm{~cd}$ & $50.9 \mathrm{bc}$ & $1.1 \mathrm{a}$ & $9.7 \mathrm{a}$ & $1.6 \mathrm{~d}$ & $11 \mathrm{e}$ & $4.6 \mathrm{e}$ & $8.5 \mathrm{~b}$ & 0.10 \\
\hline 2 & Molasses & $43.7 \mathrm{~cd}$ & $46.4 c$ & $1.2 \mathrm{a}$ & $9.7 \mathrm{a}$ & $2.4 \mathrm{~cd}$ & $15 \mathrm{de}$ & $5.0 \mathrm{de}$ & $8.5 \mathrm{~b}$ & 0.08 \\
\hline 3 & Chem. Fert. & $50.8 \mathrm{a}$ & $59.0 \mathrm{a}$ & $0.9 \mathrm{a}$ & $9.8 \mathrm{a}$ & $3.2 \mathrm{abc}$ & $20 \mathrm{ab}$ & 6.1abcd & 11.3ab & 0.05 \\
\hline 4 & $\begin{array}{l}\text { Commercial } \\
\text { EM }\end{array}$ & $44.2 \mathrm{~cd}$ & $46.1 \mathrm{c}$ & $0.9 \mathrm{a}$ & $9.5 \mathrm{a}$ & $2.4 \mathrm{~cd}$ & 16cde & $5.5 \mathrm{cde}$ & $10.8 \mathrm{ab}$ & 0.06 \\
\hline 5 & Bacterial EM & 48.3ab & $57.3 \mathrm{a}$ & $1.1 \mathrm{a}$ & $9.2 \mathrm{a}$ & 3.1abc & $24 a b c$ & $6.5 \mathrm{abc}$ & $11.9 \mathrm{a}$ & 0.05 \\
\hline 6 & $\begin{array}{l}\text { Bacterial EM + } \\
\text { Azotobacter }\end{array}$ & $46.5 b c$ & $54.9 \mathrm{a}$ & $1.3 \mathrm{a}$ & $9.5 \mathrm{a}$ & 3.1abc & $25 \mathrm{ab}$ & $6.7 \mathrm{ab}$ & $13.0 \mathrm{a}$ & 0.05 \\
\hline 7 & $\begin{array}{l}\text { Fungal EM + } \\
\text { Azotobacter }\end{array}$ & $41.8 \mathrm{~d}$ & $46.5 \mathrm{c}$ & $1.1 \mathrm{a}$ & $11.2 \mathrm{a}$ & $3.0 \mathrm{bc}$ & $22 \mathrm{bcd}$ & $5.9 \mathrm{bcd}$ & 11.3ab & 0.05 \\
\hline 8 & Fungal EM & $41.9 \mathrm{~d}$ & $48.1 \mathrm{c}$ & $1.4 \mathrm{a}$ & $12.8 \mathrm{a}$ & $3.9 \mathrm{a}$ & $31 \mathrm{a}$ & 7.1a & $13.3 \mathrm{a}$ & 0.05 \\
\hline 9 & Azotobacter & $46.0 \mathrm{bc}$ & $48.0 \mathrm{c}$ & $0.9 \mathrm{a}$ & $11.5 \mathrm{a}$ & 3.4ab & $21 \mathrm{bcd}$ & $6.2 \mathrm{abc}$ & $12.7 \mathrm{a}$ & 0.05 \\
\hline
\end{tabular}

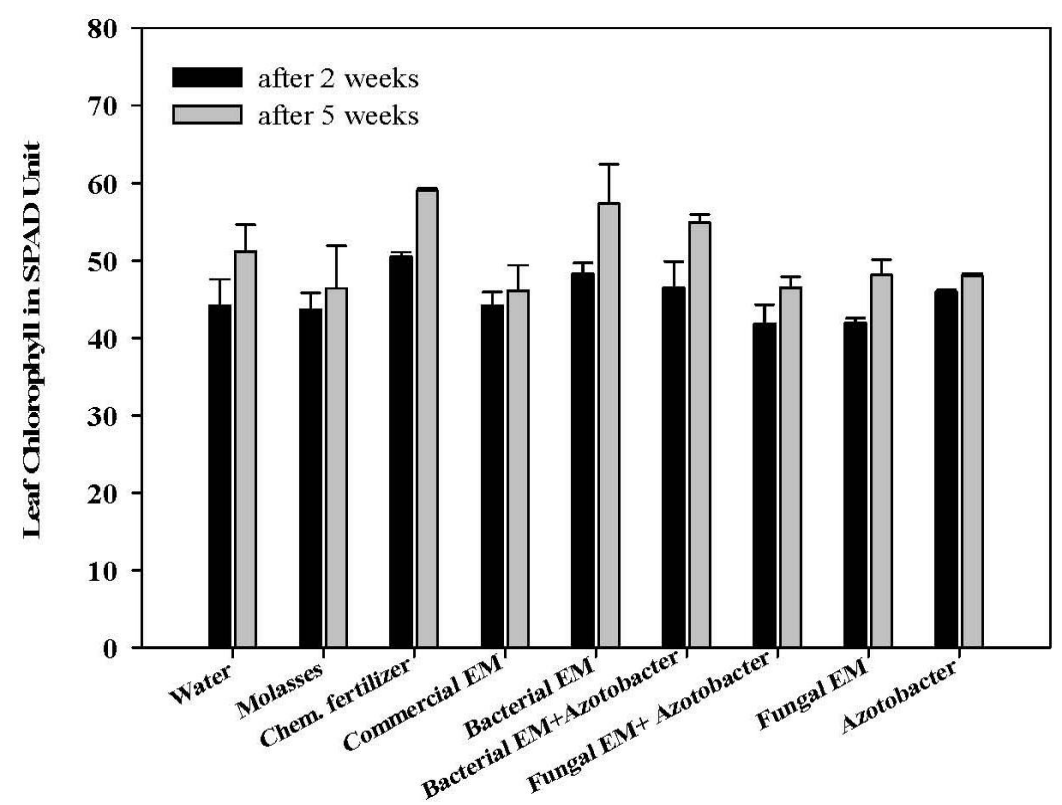

Fig. 1. Leaf color by chlorophyll meter (SPAD-502PLUS) with various treatments of effective microorganisms.

resistance (Iwaishi, 2000; Mridha et al, 1999; Xu, 2000a; Yamada et al, 2000). However, the mechanism of the effect of EM was not clear in many aspects and there might exit some kinds of active substances in the fermented solution (Xu, 2000a). Our study confirms the earlier finding implies that seedling inoculation significantly enhanced Chinese cabbage (Brassica rapa) growth. According to our results, shoot dry and fresh weight, leaf length and width significantly were increased by both bacterial and fungal inoculation. All effective microorganisms except fungal EM, increased leaf chlorophyll up to $14.2 \%$ over non-treated control after two weeks (Table 2, Fig. 1). The highest value for leaf chlorophyll appeared in the treatment of the NPK chemical fertilizer and was followed by the bacterial EM. Similarly, after five weeks the NPK chemical fertilizer showed the highest increase $15.9 \%$ in chlorophyll detected by leaf chlorophyll SPAD unit followed by $12.6 \%$ increase treated with the bacterial EM. However, the fungal EM decreased the chlorophyll in the leaves. The seedling inoculation of Chinese cabbage with fungal EM and bacterial EM supplemented with A. chroococcum significantly increased the leaf length and width. Fungal EM free from A. chroococcum showed the highest value for leaf length with $56.8 \%$ increase followed by the bacterial EM fortified with $A$. chroococcum with $52.9 \%$ increase, while the commercial EM showed $27.4 \%$ increase (Table 2). For the leaf width, the effect of effective microorganisms has similar results with leaf length. 
However, root length and root fresh weight increased with effective microorganisms inoculation, but there were no significant differences between all treatments and control. The other growth parameters such as shoot dry weight and shoot fresh weight indicated that the laboratory prepared fungal EM, bacterial EM, and bacterial EM mixed with $A$. chroococcum have significant effects on these parameters. A. chroococcum inoculation showed significant differences in the growth parameters particularly in the shoot dry weight. The fungal EM free from $A$. chroococcum showed the highest increase in both shoot dry weight and fresh weight $140 \%$ and $187 \%$, respectively. Fungal biofertilizers play an important role in promoting plant growth, health, productivity and improving soil fertility (Kaewchai et al 2009). These results were followed by the treatment of bacterial EM plus A. chroococcum that gave increase $93 \%$ and $138 \%$ for shoot dry weight and fresh weight respectively (Table 2). Results implied that the combination of $A$. chroococcum with the bacterial EM improved the growth parameters; however, A. chroococcum declined the fungal EM efficacy (Fig. 2). Microbial inoculants containing many kinds of naturally occurring beneficial microbes called 'Effective Microorganisms' have been used widely in nature and organic farming ( $\mathrm{Xu}, 2000 \mathrm{~b})$. The effects of a combined treatment of multifunctional biofertilizer (mixture of Bacillus sp. B. subtillis, $B$. erythropolis, B. pumilus and P. rubiacearum) plus $50 \%$ chemical fertilizer $(1 / 2 \mathrm{CF}+$ biofertilizer) on a treatment of with chemical fertilizer (CF) and biofertilizer on the growth of lettuce were compared by Young et al. (2003). His results showed that there was a $25 \%$ increase of lettuce yield for the treatment of $1 / 2 \mathrm{CF}+$ biofertilizer compared to that of the $\mathrm{CF}$ treatment, indicating that at least $50 \%$ of chemical fertilizer can be saved as multifunctional biofertilizer was used along with chemical fertilizer. Gholami et al. (2009) showed that leaf and shoot dry weight were significantly enhanced by bacterial inoculation and soil type. Plant growth promoting effects of PGPR strains in different crops were clearly demonstrated (Wu et al., 2005). Bacterial inoculants are able to increase plant growth and germination rate, improve seedling emergence and responses to external stress factors, and protect plants from disease (Lugtenberg et al., 2002). Jan et al (2009) proved that application of microbial inoculation is an acceptable approach for higher yield with good quality and safe for human consumption than that of chemical fertilizer. This study investigated that the bacterial EM
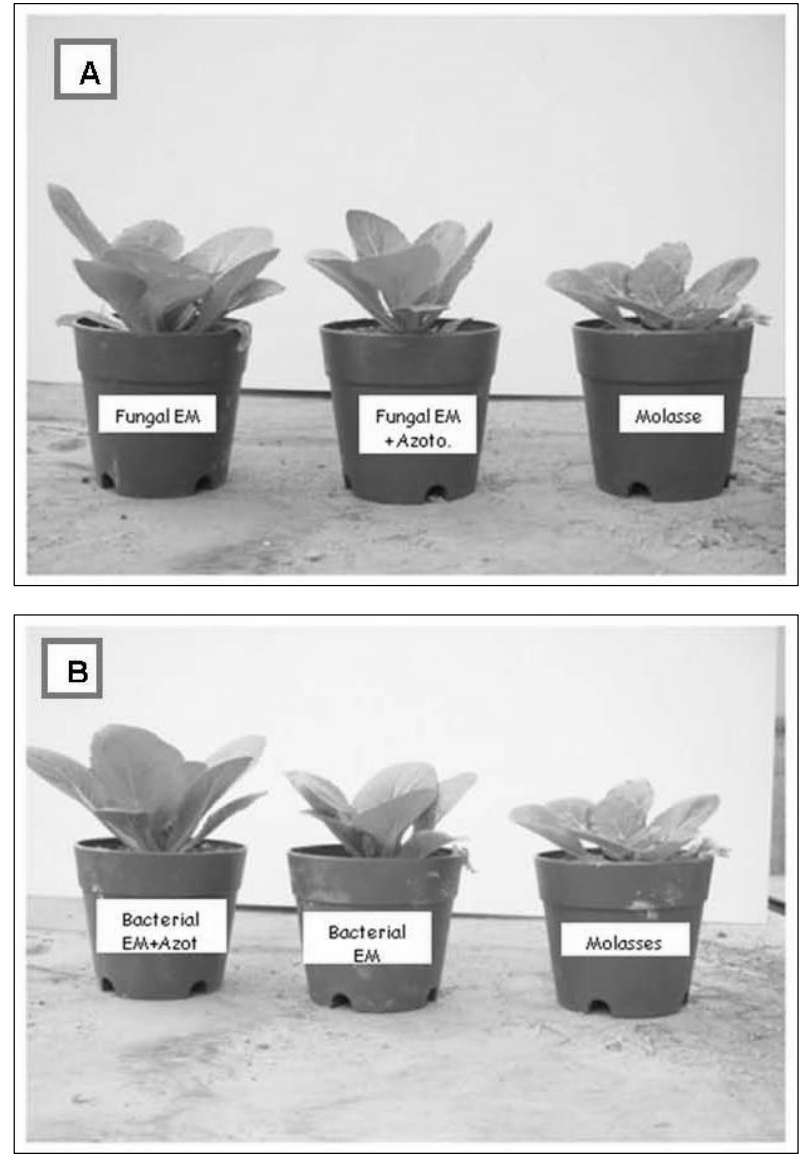

Fig. 2. The effect of $A$. chroococcum combination with the fungal EM (A) and the bacterial EM (B) on the growth parameters e.g. shoot weight and leaf length.

increased the growth of Chinese cabbage signifcantly, the growth parameters showed higher results in treatment of bacterial EM + Azotobacter chroococcum (Table 2). That may be due to $\mathrm{N}_{2}$ fixation beside that the increased synthesis of hormones like gibberellins which would have the ability to induce the activity of the plant enzymes. Bacteria of the Azotobacter genus synthesize auxins, cytokinins, and GA-like substances, and these growth materials are the primary substances controlling the enhanced growth (Mrkova-ki and Milic, 2001). Azotobacters also increase germination and vigor in young plants leading to improved crop stands (Chen, 2006). Our investigation revealed that $A$. chroococcum caused a significant increase in the growth parameters in comparing with the control, particularly in the leaf length and the leaf chlorophyll SPAD unit (Table 2). The positive effect of $A$. chroococcum on yield and plant growth after inoculation of the seeds or seedlings has been attributed to a multiple action of A. chroococcum in soil (Brown, 1974; Shende et al., 1975) such as nitrogen fixation, suppression of plant 
pathogens, production of plant growth-promoting substances, and mobilization of soil phosphate. Our results showed that the ratios of root to shoot were low with all treatments particularly the pots treated with $A$. chroococcum and the bacterial EM, however, the highest ratio of root to shoot is realized only in the water and molasses controls (Table 2). These results are in conformity with Hahne and Schuch (2004). They indicated that root shoot ratio of jojoba seedlings was always less than 1 and as small as 0.3 . They also indicated that shoot growth was favored over root growth throughout the experiment. Crush (1974) estimated that phosphate deficiency increased the ratio of root to shoot of all the legumes tested. In this study the commercial EM didn't show the best results neither in growth rate nor in microbial density of the soil. The highest value for leaf chlorophyll appeared in the treatment of the NPK chemical fertilizer and this was followed by the bacterial EM. However, the commercial effective microorganisms came in the third grade (Table 2, 3). Short shelf life, lack of suitable carrier materials, susceptibility to high temperature, problems in transportation and storage are biofertilizer bottlenecks that still need to be solved in order to obtain effective inoculation (Chen, 2007). In order to guarantee the high effectiveness of inoculants and microbiological fertilizers it is necessary to find compatible partners, i.e. a particular plant genotype and a particular azotobacteria strain that will form a good association (Mrkova-ki and Milic, 2001). According our results, plants treated with the mixture of bacteria or the mixture of fungi showed significant increases in leaf length and width, leaf chlorophyll (spad unit), fresh and dry weights, and microbial density of their soils, compared to those treated with mineral NPK. These results are supported by Abdelaziz et al. (2007) stated that plants treated with the mixture of compost and microorganisms showed significant increases in plant height, number of branches, fresh and dry weights, and number of flowers, compared to those treated with mineral NPK.

\section{The Microbial Density}

The results showed that inoculation with bacterial EM and fungal EM had a stimulation effect to increase the microbial density in soil significantly than water and molasses controls. The pots treated with bacterial EM plus A. chroococcum showed the highest bacterial density (3.75 x $10^{7} \mathrm{CFU} \mathrm{g}^{-1}$ soil), followed by bacterial $\mathrm{EM} \mathrm{(3.13}$ $\times 10^{6} \mathrm{CFU} \mathrm{g}^{-1}$ soil), while the commercial EM increased the bacterial population in soil to $2.53 \times 10^{7} \mathrm{CFU} \mathrm{g}^{-1}$ soil, and that showed $33 \%$ increase than that of the water control (Table 3). The fungal EM alone without A. chroococcum had a more stimulating effect than fungal EM combined with $A$. chroococcum based on the fungal spores viability in the soil (Fig. 5). However, the bacterial EM mixed with $A$. chroococcum recorded the highest bacterial count (Fig. 3). The soil treated with fungal EM showed fungal density of $2.86 \times 10^{6} \mathrm{CFU} \mathrm{g}^{-1}$ soil, while the fungal EM plus $A$. chroococcum treated soil showed only $4.0 \times 10^{4} \mathrm{CFU} \mathrm{g}^{-1}$ soil (Fig. 5). However, the soil of A. chroococcum treatment gave $6.6 \times 10^{5} \mathrm{CFU} \mathrm{g}^{-1}$ soil (Table 3). Water and molasses controls soil showed fungal spores density of $1.2 \times 10^{5} \mathrm{CFU} \mathrm{g}^{-1}$ soil and $3.2 \times 10^{5} \mathrm{CFU}$ $\mathrm{g}^{-1}$ soil, respectively.

Azotobacter viability appeared greater in the bacterial EM plus $A$. chroococcum soil than that of $A$. chroococcum alone treated soil. The soil treated with bacterial $\mathrm{EM}+A$. chroococcum showed $9.0 \times 10^{6} \mathrm{CFU} \mathrm{g}^{-1}$ soil, while the A. chroococcum soil had $8.8 \times 10^{6} \mathrm{CFU} \mathrm{g}^{-1}$ soil. The commercial EM had $7.32 \times 10^{6} \mathrm{CFU} \mathrm{g}^{-1}$ soil of Azotobacter.

Table 3. Effect of EM on the soil microbial density.

\begin{tabular}{llrcr}
\hline \hline & & & Microbial density $\mathrm{g}^{-1} \mathrm{soil}^{\mathrm{x}} 10^{4}$ \\
\hline No. & Treatments & Bacteria & Fungi & Azotobacter \\
\hline 1 & Water & $1,900 \mathrm{bcd}$ & 12 & 132 \\
2 & Molasses & $2,312 \mathrm{bcd}$ & 32 & 532 \\
3 & Chem. fertilizer & $572 \mathrm{~d}$ & 12 & 106 \\
4 & Commercial EM & $2,532 \mathrm{abc}$ & 52 & 732 \\
5 & Bacterial EM & $3,132 \mathrm{ab}$ & 6 & 412 \\
6 & Bacterial EM \& Azotobacter & $3,750 \mathrm{a}$ & 12 & 900 \\
7 & Fungal EM \& Azotobacter & $2,032 \mathrm{bcd}$ & 40 & 600 \\
8 & Fungal EM & $1,400 \mathrm{~cd}$ & 286 & 132 \\
9 & Azotobacter & $2,266 \mathrm{bc}$ & 66 & 880 \\
\hline
\end{tabular}




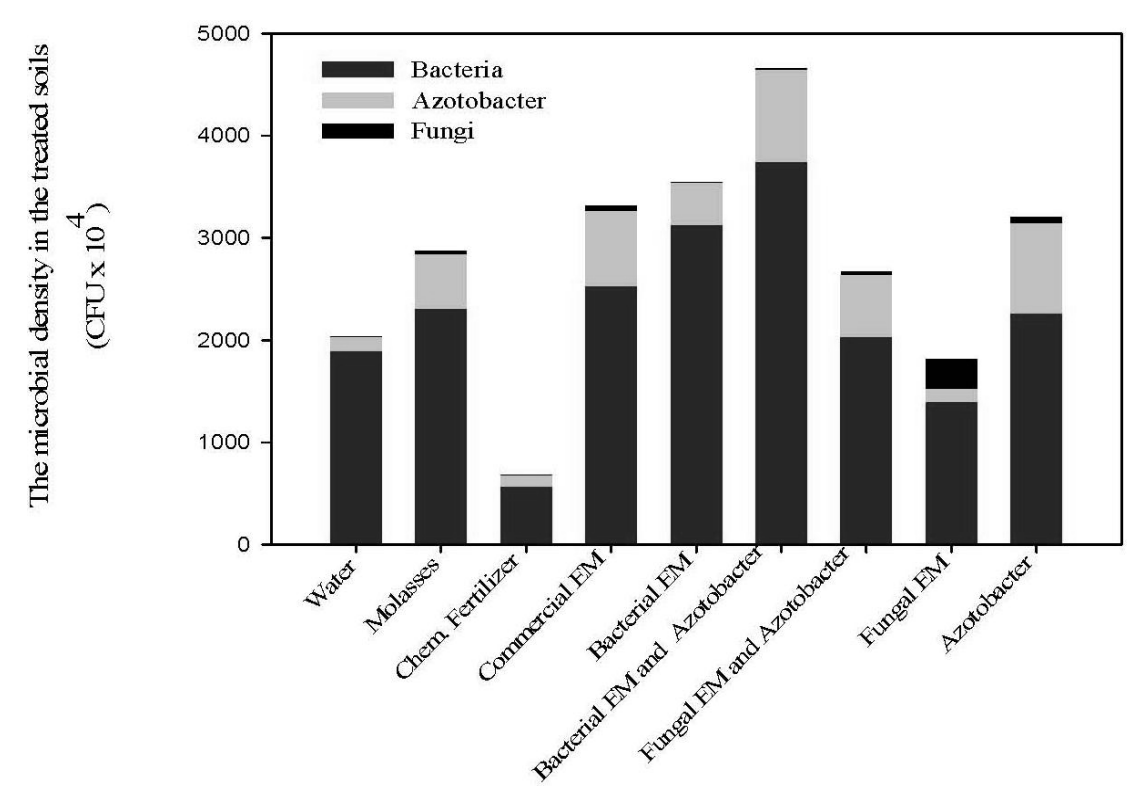

Fig. 3. Microbial density in the soil with various treatments of effective microorganisms.

However, the fungal EM plus $A$. chroococcum soil gave only $6.00 \times 10^{6} \mathrm{CFU} \mathrm{g}^{-1}$ soil of Azotobacter. The water and molasse controls have $1.32 \times 10^{6} \mathrm{CFU} \mathrm{g}^{-1}$ soil, and $5.32 \mathrm{x}$ $10^{6} \mathrm{CFU} \mathrm{g}^{-1}$ soil, respectively. The NPK chemical fertilizer diminished the Azotobacter viability to $1.06 \times 10^{6} \mathrm{CFU} \mathrm{g}^{-1}$ soil. Table 3 shows that the chemical fertilizer deteriorates the microflora inhabiting the soil showing the count 5.72 $\times 10^{6} \mathrm{CFU} \mathrm{g}^{-1}$ soil, $1.2 \times 10^{5} \mathrm{CFU} \mathrm{g}^{-1}$ soil, and $1.06 \times 10^{6}$ $\mathrm{CFU} \mathrm{g} \mathrm{g}^{-1}$ soil of bacteria, fungi, and Nitrogen fixing bacteria, respectively. The intensive use of chemical fertilizers has side effects in destroying microorganisms in the soil making plants more susceptible to the attack of disease (Abdelaziz et al., 2007). Due to the use of pesticides the productivity of agriculture systems has increased but environmental deterioration is the consequence of these ways of management. However, the use of EM as an additive to manure or as a spray directly in the field may increase the microfauna diversity of the soil and many benefits are derived from that increase (Cóndor-Golec et al., 2007).

\section{Antagonism}

To confirm our results, we carried out agar antagonism tests between all the used effective microorganisms species and $A$. chroococcum and among each others. The positive results were shown only between $A$. chroococcum and the fungal species (Fig. 4). The results showed that seedling inoculation either by bacterial EM or fungal EM significantly enhanced the Chinese cabbage (B. rapa) growth. Fungal EM without $A$. chroococcum performed better than fungal $\mathrm{EM}+A$. chroococcum in all the measurements of growth parameters (Table 2, Fig. 2). Moreover, in this study Penicillium sp. and Trichoderama were used as fungal EM. The results showed that fungal EM free from A. chroococcum showed the highest length of leaf with $56.8 \%$ increase followed by the bacterial EM fortified with $A$. chroococcum with $52.9 \%$ increase, while the commercial EM revealed only $27.4 \%$ increase (Table 2). Trichoderma species have successfully been used as biofungicides and biofertilizers in greenhouse and field plant production (Harman et al., 2004; Vinale et al., 2008). There are many Trichoderma products as fungal biofertilizers available in the market. Their applications are however related to their ability to control plant diseases and promote plant growth and development (Harman et al, 2004; Vinale et al, 2006). Trichoderma also has various applications and important sources of antibiotics, enzymes, decomposers and plant growth promoters (Daniel and Filho, 2007). Our data indicated that, in contrast the bacterial EM, the fungal EM alone without $A$. chroococcum had a more stimulating effect than fungal EM combined with $A$. chroococcum (Fig. 2). These findings may be due to the interaction occurred between $A$. chroococcum and the used fungal species. Particularly fungi are one of the major antibiotic-producing organisms. Azotobacter sp. can also produce antifungal compounds to fight against many plant pathogens. They also increase germination and vigor in young plants leading to improved crop stands (Chen, 2007). Meshram and Jager 

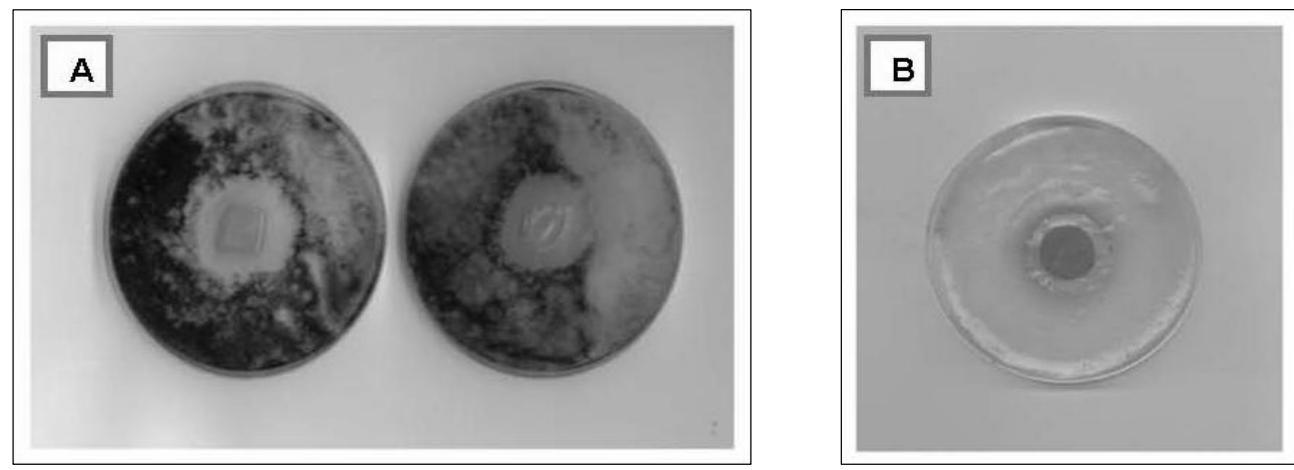

Fig. 4. The Agar disc Antagonism between $A$ chroococcum and Trichoderma sp (A). and $A$ chroococcum and P. chrysogenum (B).

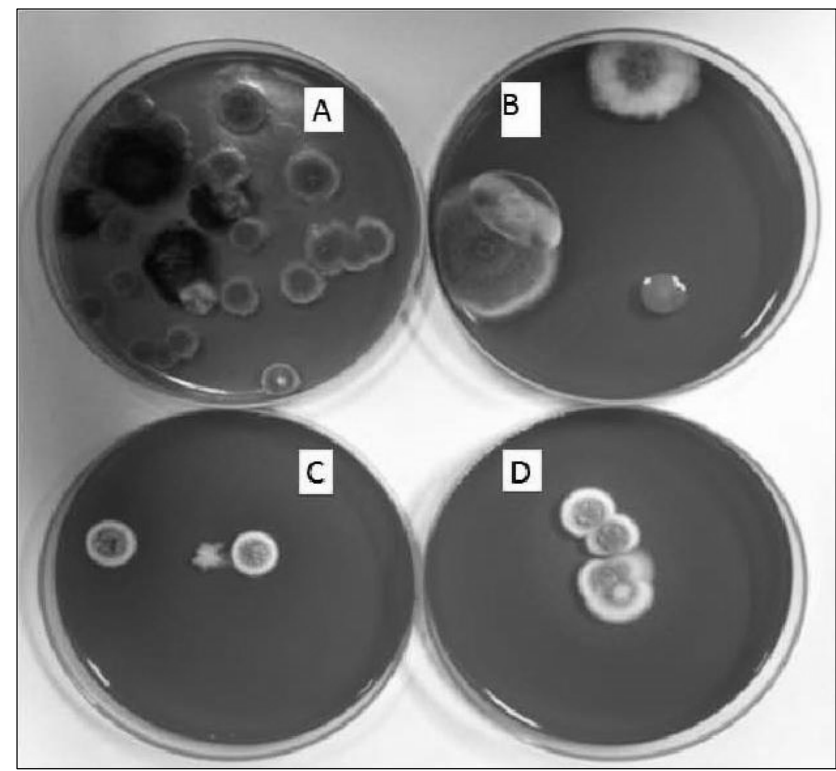

Fig. 5. The antagonism between $A$ chroococcum and the fungal species may be affected the fungal density in the fresh soil. The soil treated by fungal EM (A) showed fungal density more than the soil treated with fungal EM+ $A$ chroococcum (B), the water control (C), and the molasses control (D) were also shown.

(1983) showed that some isolates of A. chroococcum could suppress the growth of $R$. solani on agar plates; the inhibitory effect of Azobacter on R. solani on agar plates may be attributed to antibiotic substances produced by the isolates. The antagonism investigation showed positive results occurred between A. chroococcum and each of Penicillium sp and Trichoderma sp in disc agar assay (Fig. 4). As A. chroococcum has been found to exhibit antagonistic action against pathogenic soil organisms, it is worthwhile to examine its possible role in biological control of plant diseases (Meshram and Jager 1983). Therefore, according to our data the fungal EM alone without $A$. chroococcum had a more stimulating effect than fungal EM combined with $A$. chroococcum regarding the fungal spores viability in the soil (Fig. 5). Antifungal action of A. chroococcum against Aspergillus glaucus, Penicillium spp., Fusarium spp. and Alternaria spp. has been reported (Lakshmi Kumari et al., 1972). However, Hyde (2001) indicated that in nature fungi will compete against a suite of other microorganisms and this competition may induce antimicrobial production. The ability of the fungi to produce metabolites affecting Azotobacter depended greatly on the medium in which they were grown. Six Penicillium isolates strongly inhibited Azotobacter growth and six were inactive (Patel and Brown, 1969).

\section{Conclusion}

The determination of the growth parameters of $B$. rapa (Chinese cabbage) showed significant differences between the controls and the applied effective microorganisms. However, the rate of improvement varied with effective microorganisms groups. The fungal EM free from $A$. chroococcum showed the highest length of leaf with 
$56.8 \%$ increase followed by the bacterial $\mathrm{EM}+A$. chroococcum with $52.9 \%$ increase, while the commercial EM revealed only $27.4 \%$ increase, that may be explained by "antagonism interactions". According to our results the positive effect occurred only between $A$. chroococcum and the fungal species, and no antagonism occurred between $A$. chroococcum and the EM bacterial species. The fungal EM alone without $A$. chroococcum had a more stimulating effect than fungal EM combined with $A$. chroococcum regarding the fungal spore viability in the soil. However, the bacterial EM mixed with A. chroococcum recorded the highest bacterial count. Our results showed that the fungal EM soil showed fungal density of $2.86 \mathrm{x}$ $10^{6} \mathrm{CFU} \mathrm{g}^{-1}$ soil, while the fungal $\mathrm{EM}+A$. chroococcum treatment showed only $4.0 \times 10^{4} \mathrm{CFU} \mathrm{g}^{-1}$ soil. Our results showed that inoculation with bacterial EM and fungal EM has a stimulation effect to increase the microbial density present in the soil significantly than water and molasses controls. Also the results indicated that the chemical fertilizer deteriorates the microflora inhabiting the soil, while the effective microorganisms either fungal or bacterial ones increased the microbial density significantly.

Chemical or microbial fertilizer has its advantages and disadvantages in terms of nutrient supply, soil quality, and crop growth. Developing a suitable nutrient system may be a challenge to reach the goal of sustainable agriculture, however, much research is still needed.

\section{Acknowledgments}

This work was carried with the support of "Cooperative Research Program for Agricultural Science \& Technology Development (Project No. PJ0066332011)", Rural Development Administration, Republic of Korea.

\section{References}

Abdelaziz, M., R. Pokluda, and M. Abdelwahab. 2007 Influence of compost, microorganisms and npk fertilizer upon growth, chemical composition and essential oil production of rosmarinus officinalis 1. Not. Bot. Hort. Agrobot. Cluj. 35:1842-4309.

Alef, K. and P. Nannipieri. 1995. Methods in Applied Soil Microbiology and Biochemistry, Academic Press, Harcourt Brace and Company, London.

Benítez, T., M.A. Rincón, M.C. Limón, and C.A. Codón. 2004. Biocontrol mechanisms of Trichoderma strains. Int. J. Microbial. 7:249-260.

Brown, M.E. 1974 Seed and root bacterization. A. Rev. Phytopath. 12:181-197.oot bacterization. A. Rev. Phytopath. 12:181-197.

Chaudhary, M.S. and M. Iqubal. 2006. Soil Fertility Improvement with EM for Vegetable Crops. EM Database. EM Technology Network, Inc.

Chen, J.H. 2006. The combined use of chemical and organic fertilizer and/or biofertilizer for crop growth and soil fertility. International workshop on sustained management of the soilrhizosphere system for efficient crop production and fertilizer use 16-20 October 2006.

Chen, W., D.T. Jiang, and J.H. Liang. 2007. Structure and stability of aerobic granules cultivated under different shear force in sequencing batch reactors, Appl. Microbiol. Biotechnol. 76:1199-1208.

Cóndor-Golec, A.F., P. Pablo, and C.H. González. 2007. Effective Microorganisms: Myth or reality? Microorganismos efi caces: mito o realidad? (Diciembre, 2007) Facultad de Ciencias Biológicas UNMSM Rev. peru. biol. 14(2):315-319.

Crush, J.R. 1974 Plant growth responses to vesicular-arbiscular mycorhiza. New phytol. 73:743-749.

Daniel, F., S.R. De, and R.E. Filho. 2007. Peptaibols of Trichoderma. Natural Product Reports 24:1128-1141.

Fravel, D. 2005. Commercialization and implementation of biocontrol. Annu. Rev. Phytopathol. 43:337-359.

Fuentes-Ramirez, L.E. and J. Caballero-Mellado. 2005. Bacterial Biofertilizers. In: PGPR: Biocontrol and Biofertilization (ed. A. Siddiqui). Springer. Netherlands: 143-172.

Gholami, A., S. Shahsavani, and S. Nezarat. 2009. The Effect of Plant Growth Promoting Rhizobacteria (PGPR) on Germination, Seedling Growth and Yield of Maize. World Academy of Science, Engineering and Technology 49.

Hahne, K.S. and U.K. Schuch. 2004. Response of nitrate and ammonium on growth of Prosopis Velutina and Simmondsia Chinensis Seedlings. This is a part of the University of Arizona College of Agriculture 2004 Turfgrass and Ornamental Research Report, index at: http://cals.arizona.edu/pubs/crops/az1359/

Harman, G.E., C.R. Howell, A. Viterbo, I. Chet, and M. Lorito. 2004. Trichoderma speciesopportunistic, avirulent plant symbionts. Nature Reviews Microbiology 2:43-56.

Herrera-Estrella, A. and I. Chet. 2004. The biological control agent Trichoderma from fundamentals to application. In: Fungal Biotechnology in Agricultural, Food, and Environmental Applications (ed. K.A. Dilip). New York Basel: 147-156.

Hyakumachi, M. and M. Kubota. 2004. Fungi as plant growth promoter and disease suppressor. In: Fungal Biotechnology in Agricultural, Food, and Environmental Applications (ed. K.A. Dilip). New York Basel: 101-110.

Hyde, K.D. 2001. Increasing the likelihood of novel compound discovery from filamentous fungi. In: Bio-exploitation of Filamentous Fungi (eds. S.B. Pointing and K.D. Hyde). Fungal Diversity Research Series 6, Fungal Diversity Press. Hong Kong: 77-91.

Iwaishi, S. 2000. Effect of Organic Fertilizer and Effective Microorganisms ON Growth, Yield and quality of paddy-rice varieties. In:Hui-Lian Xu. James F. Parr and Huroshi Umemura (editors), Nature Farming and Microbial Applications 269-274.

Jan, S., T. Parween, Mahmooduzzafar, and T.O. Siddiqi. 2009. 
Comparative Effect of Azotobacter, Mycorrhizal Inoculum and Nitrogen Fertilizer on Biochemical, Growth and Productivity Aspects in Vicia Faba. J. Sustain. Agric. 3(4):684-693.

Kaewchai, S., Soytong, and K.D. Hyde. 2009. Mycofungicides and fungal biofertilizers. Fungal Diversity 38:25-50.

Kleifeld, O. and I. Chet. 1992. Trichoderma harzianum-interaction with plants and effect on growth Response. Plant and Soil 144:267-272.

Kloepper, J.W., B. Schippers, and P.A. Bakker. 1992. Proposed elimination of the term endorhizosphere. Phytopathol. 82:726-727.

Lakshmi, K.M., M. Vijayolakshmi, and N.S. Rao. 1972. Interaction between Azotobacter species and fungi. I. In vitro studies with Fusarium moniliforme Sheld. Phytopath. 75:27-30.

Lugtenberg, B., T. Chin-A-Woeng, and G. Bloemberg. 2002. Microbe-plant interactions: principles and mechanisms. Antonie van Leeuwenhoek. 81:373-383.

Malik, K.A., F.Y. Hafeez, M.S. Mirza, S. Hameed, G. Rasul, and R. Bilal. 2005. Rhizospheric plant-microbe interactions for sustainable agriculture. In: Biological Nitrogen Fixation, Sustainable Agriculture and the Environment (eds. Y-P. Wang, M. Lin, Z.-X. Tian, C. Elmerich and W.E. Newton), Springer. The Netherlands: 257-260.

Marin, M. 2006. Arbuscular mycorrhizal inoculation in nursery practice. In: Handbook of Microbial Biofertilizers (ed. M.K. Rai). Food products press: 289-324.

Meshram, S.U. and G. Jager. 1983. Antagonism of Azotobacter chroococcum isolates to Rhizoctonia solani. Neth. J. P1. Path. 89:191-197.

Mridha, M.A.U., H.U. Chowdhuary, H.L. Xu, and H. Umemura. 1999. Influence of Effective Microorganisms on Seed Germination and Growth of Some Crop Plants. In: Hui-Lian Xu (Editior), Nature Farming and Sustainable Environment 2:127-130.

Mrkova-ki, N. and V. Milic. 2001. Use of Azotobacter chroococcum as potentially useful in agricultural application Ann. Microbiol. 51:145-158.

Patel, J.J. and M.E. Brown. 1969. Interactions of azotobacter with rhizosphere and root-surface microflora. Plant and Soil
31(2):273-281

Pradhan, N. and Sukla, L.B. 2005. Solubilization of inorganic phosphates by fungi isolated from agriculture soil. Afr. J. Biotechnol. 5:850-854.

Shende, S.T., R.G. Apte, and T. Singh. 1975. Multiple action of Azotobacter. Indian J. Genet. P1. Breed. 35:314-315.

Subba, Rao. N.S. 2001. Soil microbiology (Forth edition of soil microorganisms and plant growth). SciencePublishers, Inc. Enfield (NH). USA.

Vinale, F., R. Marra, F. Scala, E.L. Ghisalbert, M. Lorito, and K. Sivasithamparam. 2006. Major secondary metabolotes produced by two comercial Trichoderma strains active against different phytopathogens. Lett. Appl. Microbiol. 43:143-148.

Vinale, F., K. Sivasithamparam, E.L. Ghisalberti, R. Marra, S.L. Woo, and M. Lorito. 2008. Trichoderma-plant-pathogen interactions. Soil Biol. Biochem. 40:1-10.

Wakelin, S.A., P.R. Werren, and H.M. Ryder. 2004. Phosphate solubilization by Penicillium spp. closely associated with wheat root. Biol. Fert. S. 40:36-43.

Wu, S.C., Z.H. Cao, Z.G. Li, K.C. Cheung, and M.H. Wong. 2005. Effects of biofertilizer containing $\mathrm{N}$-fixer, $\mathrm{P}$ and $\mathrm{K}$ solubilizers and AM fungi on maize growth: a greenhouse trial. Geoderma 125:155-166.

Xu, Hui-Lian. 2000a. Effects of a microbial inoculant and oganic fertilizers on the growth, photosynthesis and yield of Sweet Corn. Inoculant In:Hui-Lian Xu. James F. Parr and Huroshi Umemura (editors), Nature Farming and Microbial Applications 139-156.

Xu, Hui-Lian. 2000b. Nature Farming: History, Principles and Perspectives. J. Crop Production 3:1-10.

Yamada, K. and Xu, Hui-Lian. 2000. Properties and Applications of an Organic Fertilizer Inoculated with Effective Microorganisms. J. Crop Production 3:255-268.

Yedidia, I., N. Benhamou, and I. Chet. 1999. Induction of defense responses in cucumber plants (Cucumis sativus L.) by the biocontrol agent Trichoderma harzianum. Appl. and Environ. Microbiol. 65:1061-1070. 